\title{
BLACK THEOLOGY AND THE BLACK MASSES: \\ THE NEED OF AN ORGANIC RELATIONSHIP BETWEEN BLACK THEOLOGY AND THE BLACK MASSES
}

OA Buffel

Practical Theology

University of South Africa

\begin{abstract}
The article argues that there is still need of black theology. Although apartheid is believed to have died and blacks have political power, the socio-economic and cultural realities and conditions that necessitated black theology are still prevalent. For as long as the black experiences involve pain and suffering there will be need to reflect theologically on what it means to be black in the South African context. This time around, as black theology is resuscitated, it should not merely be an academic- intellectual enterprise of the elites but it should seriously be in such a way that it has an organic relationship with the poor and oppressed. For black theology to be sustainable it has to be done in the context of theological reflection not from the Ivory towers such as academia but together with and alongside the poor and the oppressed, as well as their ecclesiastical and social movements
\end{abstract}

Key Words: Black Theology, Liberation Theology, Organic Relationship, Poverty, Oppression

\section{Introduction}

The main argument of this article is that the masses of the poor and oppressed black people are very critical to the process of doing theology. It is for that reason that black theologians who are articulating the theological reflection that goes on in the black communities must have organic links with masses and their organisations. This lack of organic relations between black theologians and the black communities is one of the contributing factors to the weakening of this important movement of Black Theology. This is what makes it difficult for Black theology to continue to be dynamic and relevant with regard to meeting the outstanding challenges of racism which cannot disappear overnight, as well as challenges of the socio-economic and political and cultural realities that the black communities face daily.

\section{Black Theology, Dead or Alive?}

The current lull or dearth in writings and publications on Black Theology could easily give the erroneous impression that Black theology, that is, that movement that was inspired by Black consciousness in the late 1960 and early 1970's in the South African context has died.

In addition there are a number of factors inter alia that reinforce this erroneous impression namely: 
- The reality, euphoria or even the illusion of the rainbow nation that was ushered in by the establishment of the new South Africa.

- The establishment of a constitutional democracy in which equality and human rights are entrenched.

- The coming into being of the selected few from the elite who have become millionaires as a result of Black Economic Empowerment (BEE), which has not yet trickled down to the black masses, the majority of whom remain poor.

- The noble efforts that were championed by former President, Dr Nelson Mandela, and were continued by his successors with different emphases, to bring about national reconciliation and nation building. This is in addition to the work of the Truth and Reconciliation Commission, controversial as it may be to some people.

In the context of these, some would argue that there is no need to talk or write about Black Theology, or Black consciousness or even anything black for that matter, in pursuance of a united, democratic, non-sexist, egalitarian South Africa.

Lest the prophets of doom forget, this is not the first development in which Black Theology appears to be in a lull. This happened at different phases of its development. The same situation of inactivity was prevalent in the mid 1980's when one prominent Black theologian, Goba (1986:58) correctly lamented that: "there are those who have the false impression that Black Theology is something of the past or it is dead" Goba (1986:58) dismissed that erroneous impression by stating that: "Black Theology is alive, because it has become the way of doing theology-a vehicle through which we articulate and express our faith". According to Goba (1986:58) it is dead only to those who continue to be enslaved by a colonial type of theology, or a reactionary theology that has failed miserably to address itself to our situation of dehumanisation and oppression. Black Theology was and is still not a passing fad and like any movement it inevitably passes through various phases. Goba saw it as an enterprise which is a theological pilgrimage that has and will continue to give expression to the faith of blacks within an ongoing struggle for liberation. At one of the seminars of the 1980's which was aimed at reviving Black Theology, Goba (1986:58) protested to that notion of a theology that needed to be revived:

The significance of the seminar is that we are not here to resuscitate Black Theology from its slumber but we are here to sharpen and deepen our respective methodologies vis-a-vis the current ongoing struggle. It was to sharpen the tools or 'swords' in order to challenge again the black Christian community to participate meaningfully in the struggle for authentic liberation (Goba 1986:58; cf. Motlhabi 2008:11).

It is for that reason that Goba rejected the erroneous impression that Black Theology is either past or dead. The same situation similar to the 1980's is happening again, to the extent that it raises serious concerns about the current status of Black Theology. In the most recent publication on Black Theology, Motlhabi (2008:x) expresses his concerns thus:

I am concerned about the current status of Black Theology in the country. I have always

lamented the fact that it has never attained its full maturity.

Motlhabi (2008:x), like Goba does not seem to believe that Black Theology is dead, but rather that it seems to have lost its bearing and sense of direction, especially since the political change that took place since 1994. The current dearth in writings and publications on black theology does not mean that black theology is dead. It is therefore too premature to write the obituary of Black Theology. According to Motlhabi (2008:10) there were some whispers from some sources about the apparent death of Black Theology. Other than the end of apartheid particularly from the statutes, and the bringing down of boards at entrances 
of separate amenities such as 'Whites only' and 'Blacks and dogs not allowed', the realities of dehumanisation, suffering, oppression and exploitation, and class and gender discrimination that Black Theology grappled with are still prevalent. These are the realities that according to Maimela have been created by human beings. Maimela (1986) had pointed out to the truth that "Black Theology is a product of the awareness that black oppression and black exploitation are man-made (sic)". Feminist theologians and gender activists will correctly add the oppression of women to Maimela's list of human-made problem. Black theology was born out of the awareness by blacks that they are not poor and oppressed by accident or by divine design, rather they are made poor, powerless and they are oppressed by another rich and socio-politically (and economically) powerful racial group of whites (Maimela 1986:102). For as long as there are these people-created problems such as black oppression, gender oppression, black exploitation and black poverty, there will always be need to have Black Theology. However this movement will continue to suffer paralysis from time to time for as long as it done only from the ivory towers of academic institutions far removed from the grassroots where it should be rooted and developed. Thus it can only be sustainable if there is an organic relationship between it and oppressed poor and their community based and faith-based organisations.

\section{What is Black Theology?}

This lull or dearth with regard to writings and publications on Black Theology, has somewhat stifled the development and growth of Black Theology as movement and as an academic discourse and as a result, as we revisit this we are forced to be stuck in the two stages identified by Mosala and Tlhagale (1986), that is, the polemic and definitional and the quasi-academic phases of Black Theology. Motlhabi (1986:4) decries the fact that the South African writings on Black theology have not been as outstanding as the black American writings and that they bordered mainly on definitions and have not outgrown that stage. It is for that reason that inevitably some recapping is required with regard to understanding what Black Theology is all about.

A leading exponent of Black Theology, Cone (1987:11) defines Black Theology as a 'the theology of black liberation'. Cone (1987:1) extends this definition by stating that Christian theology is and should be a theology of liberation. This understanding is correctly echoed by Pityana (1972:42), Boesak (1986:9) and others (cf Goba 1986:60; Sebidi 1986:21; Pityana 1994:177). According to Cone (1972:28) it is a religious explication of the need for black people to define the scope and meaning of black existence in a white racist society. Thus black theology placed black identity in a theological context.

When theology is not about liberation then it is worthless and not worth pursuing. In fact it ceases to be theology, as Cone (1987:1) points out that "theology ceases to be theology of the gospel when it fails to arise out of the community of the oppressed". Cone (1975:vi) had earlier dismissed any theology that is apathetic towards liberation of the poor and oppressed as being unchristian. He said: "Theologically any analysis of the gospel which did not begin and end with God's liberation of the oppressed is ipso facto unchristian". To Cone and others any theology that is indifferent to the theme of liberation is not Christian theology (cf. Cone 1987:vii). This understanding of a theology preoccupied with liberation of the oppressed and downtrodden is also shared by Motlhabi (1986:46), who said: "The message of Black Theology, as already seen, is liberation: to set the downtrodden free". According to Motlhabi (1986:46) Black Theology falls within the umbrella of Liberation Theology (cf. Boesak 1986:1). Goba (1986:60) adds other useful dimensions to the understanding of Black Theology by defining Black Theology as: 
Black theological reflection that is also a critical reflection on the praxis of Christian faith, one which participates in the ongoing process of liberation within the black community.

In black theology blacks are reflecting about their faith as they engage meaningfully in the struggle of the black community. According to Moore Black Theology (1973:viii): "is a theology of the oppressed, by the oppressed, for the liberation of the oppressed". It is a way of thinking and acting by black Christians as they attempt to discover the socio-economic political and cultural implications of their faith (cf. Goba 1986:60). According to Moore (1973:5) Black Theology is a situational theology, and this is a chief distinguishing characteristic of Black Theology (cf. Boesak 1986:13). Blacks are attempting to come to terms theologically with their black situation. It is the situation of blacks that gave birth to Black Theology, as Maimela (1990:191) correctly points out:

Black Theology, born out of the situation of oppression, is a theological protest against white racial domination. It is a theology which aims at reflecting on black experience in the light of the gospel.

It was always in the mind of the exponents of Black Theology that theology had to be done not for but together with the oppressed people of the country. It had to emerge from within the struggle of the oppressed. In driving this point home Chikane and Tsele (1994:1) cite the conclusion of the 1984 conference which stated:

In our research/study we must bear in mind the resolution contained in the Final Statement of the Seminar that we develop together with the oppressed people of this country a black theology of liberation and this theology must emerge from "within the struggles of the oppressed people.

Chikane and Tsele (1984:1) correctly acknowledged that that the remaining task of Black Theology had not been undertaken by the time of the 1984 conference. That task cannot be carried out alone by academics from the ivory towers of Universities without ensuring that there is an organic relationship with those who are in pain and suffering as a result of oppression, sexism, exploitation and poverty. Only that can make Black theology a sustainable enterprise. According to Chikane and Tsele (1984:2) as a theology of the people:

It must go out from comfortable conference centres, offices and seminaries/universities into the streets with the people. This means that Black Theologians must die with the people and bear the pain with them in order to be able to write an authentic theology of liberation.

This theology of the people is made authentic by the fact that it arises out of the struggles of those who are suffering and oppressed.

\section{Black Theology and a New Methodology}

Black Theology is seen as a new way or method of doing theology. According to Boesak (1986:1) black theology denotes a fundamentally different approach to Christian theology, a new way of looking at the world we live in and at the responsibility of the church in the world. Boesak (1986:10) goes on to say that it is new way of theologising, a new way of believing (cf. Pityana 1994:174). De Gruchy (1985:87) correctly says that the emergence of Black Theology brought with it a new methodology to the debate.

Furthermore De Gruchy (1985:94) sees Black Theology as a methodological partner of Liberation Theology. However, I would argue that it is not just a mere methodological partner, but rather it is Liberation Theology from a particular perspective. Some would even 
argue that it is a brand of liberation theology. One is inclined to agree with Bosch (1991:432) who saw liberation theology as a multifaceted global phenomenon that manifested itself in various theologies from the Third World (or rather the developing world). In the South African context liberation theology is manifested as Black Theology, even against the protest of others to whom the term 'Black' sounds undesirable or unpalatable, especially some whites who dismiss it as 'an ideological distortion of the gospel' or as 'racism in reverse' (cf. De Gruchy 1985:95). No white theologian or Christian has the right to dictate to blacks or black theologians how to reflect theologically from their own situation of blackness marked by racism which may be gradually declining, oppression, sexism, dehumanisation, exploitation and poverty. Therefore Black Theology is and should be engaged in the process of 'doing theology' in the context of this blackness. According to Chikane (1985:98) this new methodology is expressed in the phrase 'doing theology', which is emerging as a dominant methodology in the Third World. Chikane (1985:100) proceeds with an argument that 'doing theology' means action and reflection on one's activity and involvement with the people, and participation in their struggles. The theologian cannot afford to 'think theologically' without being involved with the people of God, in the activity of God. They have 'to do theology' in action. Doing theology in action cannot be sustainable without the organic relationship with the masses of the poor and oppressed who bear the brunt of suffering, oppression, dehumanisation, sexism, exploittation and poverty. The masses of the poor are also the primary interlocutors of Black Theology (cf. West 1999:14). These primary interlocutors are not just passive recipients of the charity of the rich and the intellectuals, but they are and should be centrally involved in the articulation of their theology of liberation. They have ownership of the process of theological reflection and action.

\section{Theological Reflection Predates the Dawn of Black Theology}

Although Black Theology, as a conscious, systematic and academic reflection on black experience, arose in the 1960's in America and 1970's in South Africa, the history of the struggle against white racism, domination and oppression goes back much further than this (cf. Maimela 1990:190). Already in the 1980s this fact was demonstrated concretely by the emergence of the African Initiated Churches (cf. Motlhabi 2008:2; De Gruchy 1985:89). According to De Gruchy (1985:89) this emergence of the African Initiated Churches, the indigenous church movement of the late nineteenth century represented the first attempts by black Christians to break free from ideological dominance in the church and society. De Gruchy refers to this as 'the first contextual theology in South Africa'. Nobody who is sane can argue that all along before the $1960 \mathrm{~s}$ and 1970's blacks never reflected theologically on what it meant to be black in a context of a racist, oppressive, and dehumanising society. Much as Cone's work was helpful and influential in the development of the South African brand of Black Theology, South Africans were not incapable of theological reflection without Americans. According to Goba (1986:58):

Black Theology is a very important movement within the black Christian movement. It is a reaffirmation of a vision that was born long ago, when some of the early black Christian leaders such as Rev. Dwane and Rev. Mokone decided to break away from the imperial theology that dominated the lives of black Christians in this country.

He goes on to argue correctly that there is a sense in which in Black Theology we are involved in a theological pilgrimage that has and will continue to give an expression to our faith within an ongoing struggle for liberation. What later became academic discourse was preceded by ongoing struggle for liberation which must have been accompanied by some 
theological reflection within the black communities in general and the black churches in particular.

\section{The Black Community and the Black Church in Black Theology}

From various attempts at definition and understanding of Black Theology, there is a common denominator, which is very critical to theological reflection, that is, the black community. This brand of theology or theological reflection arises out of the experience of the black community, out of their situation. That is the situation marked by dehumanisation, pain and suffering, oppression, sexism and exploitation. This black community is what Mosala (1989:x) refers to as 'the terrain of struggle for the liberation of the poor and exploited'. This is the wider black community which according to Mosala (1989:2) was to be the real ground in which black theology would take root and develop. Boesak (1986:9) also points out to the truth that Black Theology is born in the community of the oppressed, and it takes seriously the black experience and the black situation and grapples with suffering and oppression. Black theologians are and should be doing this theology alongside and together with the Black community. Cone (1987:10) takes it further and argues that Black Theology is accountable to the black community. This is in line with the argument of Mosala and Thagale (1986:xviii), that what happens in the black struggle affects the process of theologising about the struggle. Inevitably the black church is part of the wider community of blacks. During the struggle for liberation the terrain of struggle was not only within the broader community but included the black church. During that time, the black church was according to Mosala (1989:xi):

That refuge to which black people escaped from the brutalities of racism and capitalistic

exploitation and which also served as a resistance base.

It is public knowledge that church buildings were used as venues of meetings and rallies during the struggle for liberation. Who can forget the roles played by church buildings such as Regina Mundi in Rockville, Lutheran Church Centre in Jabavu, Ipelegeng Anglican Centre Soweto, Ikageng Lutheran Youth centre in Mangaung and many others in townships throughout South Africa? However apart from serving as venues, many black activists who were being either harassed or sought by the 'system' found refuge in many church buildings.

In the South African context, the struggle for a free, democratic South Africa was based on the religious conviction of the people of community of faith (cf. MacMaster 2008:6). The church's involvement in the struggle for liberation was spearheaded by church leaders, lay and ordained, who literally put their bodies on line, leading protest marches, enduring teargas canisters and detention without trial and banning orders etc. (cf. MacMaster 2008:6). Among the leaders we could mention the following: Albert Luthuli, ZK Matthews, Trevor Huddleston, Desmond Tutu, Beyers Naude, Allan Boesak, Frank Chikane, Khoza Mgojo, Tshenuwani Farisani, Molefe Tsele and many others across denominational lines. These church leaders were organisationally linked with the organisations of the people in the form of churches and community-based organisations and non-governmental organisations that directly served the black masses.

According to Mosala (1989:xi) when Black Theology emerged in the context of Black consciousness movement its immediate target was the Christian church, and its theology. At that time the point of contention was the perceived acquiescence of the Christian church and its theology in the oppression and exploitation of the black people. Mosala (1989:1) proceeds to argue as follows regarding the role of the church: 
That not only was the church relatively silent on the question of oppression but the thoroughly Western and white outlook of its theology helped reproduce the basic inequalities of an apartheid society. Consequently black activists emphasised the need for a black theology of liberation.

This echoes what Moore (1973:viii) said earlier about the role of the Christian church in South Africa in its support of political oppression of the black people. He said:

While the colonists were busy with the process of robbing the people of their land and their independence, the churches were busy, undermining the will of the people to resist. This was done in a number of subtle and not so subtle ways. In the first place the church made it plain that everything African was heathen and superstitious barbarism.

During that time the church had become what Biko called 'very irrelevant and in fact an ivory tower' (Biko 1978:57). According to Motlhabi (2008:2) the colonial church, particularly the white church was irrelevant with regard to ministering to the physico-spiritual needs of black people. The Christian churches and especially the theological Seminaries and colleges, were therefore strategically placed to be the starting point of theological reflection (cf. Mosala 1989:2). These were targeted as part of the wider black community in which much of the pain, suffering, oppression and dehumanisation were experienced. At that time black theology was according to Pityana (1994:174), steeped in the black church and in the faith and life of the black people. This was in line with the purpose of black theologians at its initial stages, which was according to Motlhabi (1972:2): 'to reach as many churchmen (sic) as possible'. An important task of black theology was to make an important contribution in the struggle for liberation, and an important terrain of that struggle was the black church. In support of this Mosala (1989:2) argued that:

There was never any doubt, therefore, that black theology was to be developed as an instrument of struggle for the liberation of the oppressed and exploited black people in South Africa.

It is unfortunate that the theological reflection that was rooted in praxis, later only became a prerogative of academics at Universities. Furthermore, the lack of organic links with organisations of the black masses was brought in by the fact that a significant number of black academics were sidelined by many of their churches and ecclesiastical authorities. Therefore many of them were engaged in doing theology from libraries and offices instead of from the 'terrain of struggle'. I still recall vividly and painfully the discussions in one session of a Church Council, the highest decision-making structure of that church, which took a decision to give a warning to a then promising black and very gifted theologian and an activist minister who was appointed in a contract position at a University that had some prominent black theologians. He had to either resign or have his services terminated. That theologian was later to make an important contribution in theological discourse, as well as a contribution as an activist. There are many others who were marginalised by church authorities and denied opportunities to maintain organic links with churches as important terrains of the struggle. This is a major argument of this article, that it was unfortunate that Black Theology and many of its leading exponents at one stage did not have any organic relationship with the black church nor with the wider black community.

\section{Organic Relationship between Black Theology and the Black Masses}

When Black Theology started, as what Sebidi (1986:20) referred to as 'a wave raising phenomenon', it was not started by academics at academic institutions, but by activist that were involved at different levels of the liberation struggle. According to Pityana 
(1994:175), Black Theology saw itself as a movement for the mobilisation of the black people within and outside the churches. One of its tasks was directed at building a mass movement.

One serious setback and weakness of Black Theology over the years is that it became delinked from the black community that it was supposed to serve. It later became a purely academic exercise of academics, as it degenerated into a theological reflection done at Universities. It became a monopoly of educated black Christians. Pityana (1994:180) raised this critique against it as follows: "Black Theology appears to be isolated in academic institutions, engaged in abstruse academic discourse" Pityana (1994:180) gives the following reasons for that development:

Perhaps this is due to the fact that the leading Black theologians were no longer pastors and parish ministers or even seminary lecturers and have therefore not been able to impact on the life of the church at the base of ecclesial level. Some may ask: Has Black Theology outlived its usefulness... On the other hand it could be that Black Theology no longer captured the imagination of the oppressed because political strategies have now multiplied and opportunities have extended.

What compounded the matters further were that the New South Africa offered opportunities for activist ministers and leading black academics who joined the civil service, statutory bodies of the country such as Commissions and managerial positions that were available at institutions of higher learning. Some even went into business (cf. Motlhabi 2008:13). Regarding the exodus of leading prophets of the church from the leadership of the churches and academic institutions Maluleke (2005:105) expressed his reservations as follows:

I was flabbergasted that the new South African governments (of both Mandela and Mbeki) had taken some of the foremost leaders and theologians, instating them in political and quasi-political positions.

This exodus contributed to the weakening of the movement of the Black Theology, as well as the dilution of the prophetic voice of the church and its theologians. Furthermore this led to the demise of the only mouthpiece of Black Theology in academia, the Journal of Black Theology in 1998, as well as in later years the demise of the Institute of Black Theology. This affected the effectiveness of the ecumenical body that at one stage was the theological and prophetic voice of the church that at one stage was unequivocally on the side of the poor, oppressed and the exploited, namely the South African Council of Churches. There may be other factors that also contributed to all of these and that may be debated at another time, but the brain drain played a role that is not insignificant in impoverishing the black and prophetic voice.

One theologian who strongly raised this critique against black theology was Mosala (1989:2) who argued that Black Theology has been unable to develop organic links with the popular struggles of especially the black working class, the most exploited segment of the black community. This was a critique that unfortunately was not taken seriously by most black theologians including Mosala himself. There are no demonstrable efforts over the years of any efforts to work with and mobilise the masses in view reflecting with them theologically with regard to what it means to continue to be poor, oppressed, exploited regardless of what the New South Africa promises the poor masses, but fails to deliver. There is also limited or no evidence of empirical research in many of their articles on black theology that includes efforts to listen to what the poor and oppressed are saying. There is limited or no evidence of any efforts to journey with the poor as they struggle to liberate themselves from poverty, oppression, sexism, dehumanisation and exploitation. 


\section{Conclusion}

There is no doubt that the oppressed and poor blacks will continue to reflect theologically about their situation and the associated suffering that goes with that, even if their theological reflections do not make newspaper headlines nor find ways into accredited theological journals. They will continue to do that because of the reality of severe pain and suffering as a result of poverty that is entrenched in socio-economic and political structures of the South African society. The end of apartheid did not suddenly bring down those structures that ensure that 'the poor remain poorer while the rich become richer', as a leading Afrikaner academic, Prof S. Terreblanche also acknowledged:

When in 1994, a democratically elected government came to power, it inherited a contradictory legacy; the most developed economy in Africa on the one hand, and major socio-economic problems on the other (Terreblanche 2002:25).

According to Terreblanche what makes the socio-economic problems so pressing, is that it is mostly blacks, who are at the receiving end of such problems. This is also supported by Archbishop N. Ndungane who pointed out that South Africa has inherited from apartheid a legacy of economic and social distress and dysfunctions (Nungane 2003:20).

It is in the context of these social distress and dysfunctions that most blacks have to survive and struggle for liberation, as well as grapple theologically with what it means to be black. When that happens, pastors, prophets and theologians are nowhere to be found. This call for the question raised by MacMaster (2008): "Where have all the pastors (theologians) gone?" It is in the midst of those struggles, that is, in what liberation theologians refer to as 'the belly of the whale' that they are to journey with the poor and oppressed (cf. Hertzog 1970; Rieger 1999). And that can only happen provided theologians are prepared to work not only from the comfort of their offices and personal computers, but from the existential experience of the poor and the marginalised. They must be prepared to listen to the poor and accompany them as they journey in the struggle for liberation (cf. Buffel 2007:55). This to be done in line with what Frei (1989:32) says:

The liberation theologian is not an armchair intellectual confined to libraries and lecture room, dedicated to an academic rigour antiseptically protected from the current conflicts.

Black theologians therefore must be part of the experience of the masses and from that situation work together with the masses to reflect on what it means to be poor, oppressed and dehumanised. They have to take seriously the challenge of Motlhabi (2008:15):

If Black Theology is to survive and remain relevant in South Africa, therefore, it must undergo a reorientation and readjustment in its approach to socio-ethical issues so that it can focus on these new developments in, and changed problems of, the new South Africa.

Black theologians have no choice but to be organically part of the black masses and to journey with the masses as theology is being done in the context of the many socio-economic and political challenges that the masses are facing. 


\section{BIBLIOGRAPHY}

Biko, S 1972. Black consciousness and the quest for true humanity, in Essays on Black Theology by Motlhabi M (ed.), Braamfontein, University Christian Movement, pp. 17-27.

Biko, S 1978. Black consciousness and the quest for humanity, in I write what I like, by Stubbs A (ed.). Johannesburg, Heinemann, pp. 87-98.

Bosch, D 1991.Transforming Mission: Paradigm Shifts in Theology of Missions. New York. Orbis Books.

Boesak, AA 1986. Farewell to Innocence: A socio-ethical Study on Black Theology and Black Power, New York. Orbis Books.

Buffel, OA 2007. Pastoral care in a context of poverty: A search for a pastoral care model that is Contextual and Liberating. Unpublished PhD Thesis. University of Pretoria.

Chikane, F and Tsele, M 1984(eds.). Conference Report: Black Theology and the Black Struggle. St Francis Xavier-Cape Town 10-14 September 1984. Braamfontein, Institute of Contextual Theology.

Chikane, F 1985. Doing Theology in situation of conflict, in Resistance and Hope: South African Essays in honour of Beyers Naude, Cape Town, David Phillip, pp. 98-102.

Cone, JH 1972. Black Theology and Black Liberation, in Essays in Black Theology by Motlhabi M (ed.), Braamfontein. University Christian Movement, pp. 28-36.

Cone, JH 1975. God of the Oppressed. Minneapolis, Seabury Press.

Cone JH 1986. Speaking the truth: Ecumenism, Liberation and Black Theology, Grand Rapids, William Eerdmans Publishing Company.

Cone, J 1987. A Black Theology of Liberation. New York, Maryknoll, Orbis Books.

De Gruchy, J 1985. Theologies in Conflict: The South African debate, in Resistance and Hope by De Gruchy J and Vila Vicencio C, Cape Town, David Phillip, pp 85-97.

Goba, B 1986. The Black consciousness Movement: Its impact on Black Theology, in The Unquestionable right to be free by Mosala I and Tlhagale B, Johannesburg, Skotaville, pp 57-69.

Herzog, F 1970. Theology of Liberation, in Continuam 7(4) (winter 1970).

MacMaster, LM 2008. Where have all the pastors gone? A case for Public Pastoral care in a Democratic South Africa experiencing pains, in Journal of Black Theology in South Africa No. 132 (November 2008), pp. 3-15.

Maimela, SS 1986. Current themes and emphases in Black Theology, in The Unquestionable Right to be fee by Mosala I and Tlhagale B (eds.), Johannesburg, Skotaville pp. 101-112.

Maimela, SS 1990. Modern Trends in Theology. Johannesburg. Skotaville.

Maluleke, TS 2005. Reconciliation in South Africa: Ten Years Later, in Journal of Theology in South Africa, No. 123, (November 2005), pp.105-120.

Mofokeng, T 1986. The evolution of the Struggle and the Role of Black Theology, in The Unquestionable right to be free, by Mosala I and Tlhagale B (eds.) Johannesburg, Skotaville, pp. 113-128.

Moore, B 1973. The Challenge of Black Theology. Atlanta. John Knox Press.

Mosala, I 1986. The Use of the Bible in Black Theology, in, in The Unquestionable right to be free, Mosala I and Tlhagale B (eds.), Johannesburg, Skotaville, pp. 175-199. 
Mosala, I 1989. Biblical Hermeneutics and Black Theology. Grand Rapids, William Eerdmans.

Motlhabi, M 1972 (ed.). Essays on Black Theology, Johannesburg, University Christian Movement.

Motlhabi, MG 1986. The Historical Origins of Black Theology, in The Unquestionable Right to be free by Mosala I and Tlhagale B (eds.), Johannesburg, Skotaville, 37-56.

Motlhabi, M 2008. African Theology/Black Theology: Looking Back, Moving Forward, Pretoria, University of South Africa.

Ndungane, N 2003. A world with a human face: A voice from Africa. Cape Town. David Phillip.

Pityana, B 1972. What is Black consciousness? In Essays in Black Theology by Motlhabi M (ed.), Braamfontein, University Christian Movement, pp. 37-43.

Pityana, B 1994. Black Theology, in Doing Theology in Context, by De Gruchy J and Vila-Vicencio C, Cape Town, David Phillip, pp. 173-183.

Sebidi, L 1986. The dynamics of the Black struggle and its implications for Black Theology, in The Unquestionable right to be free by Mosala I and Tlhagale B (ed.), Johannesburg, Skotaville, pp. 1-35.

Terreblanche, S 2002. A history of inequality in South Africa 1652-2002. Pietermaritzburg. University of Natal Press.

West, G 1999. The Academy of the Poor: Towards a Dialogical Reading of the Bible in the South African Context, Pietermaritzburg. Cluster Publications. 